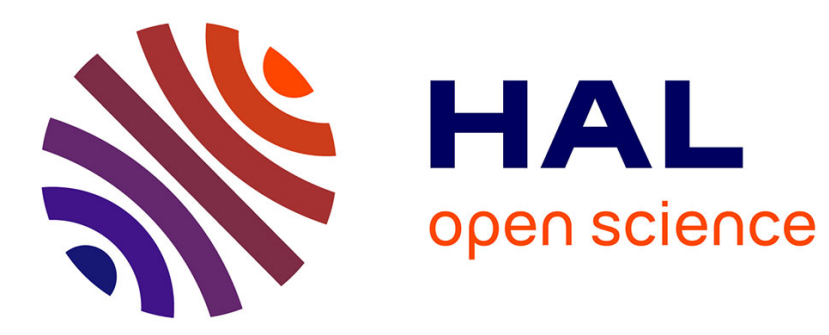

\title{
Preparation of Bismuth Titanate Films by Electron Cyclotron Resonance Plasma Sputtering-Chemical Vapor Deposition
}

H. Masumoto, T. Hirai

\section{- To cite this version:}

H. Masumoto, T. Hirai. Preparation of Bismuth Titanate Films by Electron Cyclotron Resonance Plasma Sputtering-Chemical Vapor Deposition. Journal de Physique IV Proceedings, 1995, 05 (C5), pp.C5-671-C5-677. 10.1051/jphyscol:1995580 . jpa-00253942

HAL Id: jpa-00253942

https://hal.science/jpa-00253942

Submitted on 1 Jan 1995

HAL is a multi-disciplinary open access archive for the deposit and dissemination of scientific research documents, whether they are published or not. The documents may come from teaching and research institutions in France or abroad, or from public or private research centers.
L'archive ouverte pluridisciplinaire $\mathbf{H A L}$, est destinée au dépôt et à la diffusion de documents scientifiques de niveau recherche, publiés ou non, émanant des établissements d'enseignement et de recherche français ou étrangers, des laboratoires publics ou privés. 


\title{
Preparation of Bismuth Titanate Films by Electron Cyclotron Resonance Plasma Sputtering-Chemical Vapor Deposition
}

\author{
H. Masumoto and T. Hirai
}

Institute for Materials Research, Tohoku University, 2-1-1 Katahira, Aoba-ku Sendai, 980-77, Japan

\begin{abstract}
Bismuth titanate $\left(\mathrm{Bi}_{4} \mathrm{Ti}_{3} \mathrm{O}_{12}: \mathrm{BIT}\right.$ ) thin films were prepared on the $\mathrm{Pt}$ courted $\mathrm{MgO}(100)$ substrate by electron cyclotron resonance plasma sputtering-chemical vapor deposition (ECR plasma sputtering-CVD). $\quad \mathrm{Bi}_{2} \mathrm{O}_{3}$ was used as a sputtering target and tetra-isopropoxy-titanium $\left[\mathrm{Ti}\left(\mathrm{i}-\mathrm{C}_{3} \mathrm{H}_{7} \mathrm{O}\right)_{4}\right]$ as a CVD source. The composition of films was controlled by changing $R F$ power $\left(P_{R F}\right)$ of $\mathrm{Bi}_{2} \mathrm{O}_{3}$ target and $\mathrm{Ti}$ source temperature $\left(\mathrm{T}_{\mathrm{Ti}}\right)$. The stoichiometric BIT film was prepared under the condition of $P_{\mathrm{RF}}=500 \mathrm{~W}, \mathrm{~T}_{\mathrm{Ti}}=63^{\circ} \mathrm{C}$, deposition temperature of $650^{\circ} \mathrm{C}$ and deposition rate of $14 \mathrm{~nm} / \mathrm{min}$. Epitaxial relationships between the BIT film and the substrate were determined $\mathrm{MgO}(100) / / \mathrm{Pt}(100) / / \mathrm{BIT}(001)$ and $\mathrm{MgO}<100>/ / \mathrm{Pt}<100>/ / \mathrm{BIT}<110>$. The remanent polarization and coercive field measured by a Sawyer and Tower bridge circuit at $50 \mathrm{~Hz}$ were $1.12 \mu \mathrm{C} / \mathrm{cm}^{2}$ and $46 \mathrm{kV} / \mathrm{cm}$, respectively.
\end{abstract}

\section{INTRODUCTION}

Bismuth titanate, $\mathrm{Bi}_{4} \mathrm{Ti}_{3} \mathrm{O}_{12}$ (BIT), which consists of $\mathrm{Bi}-\mathrm{O}$ layers and pseudo-perovskite BiTi-O layers, is a ferroelectric material with a curie-point $(\mathrm{Tc})$ of $675^{\circ} \mathrm{C}$. BIT is expected to be a useful material for ferroelectric memories and piezoelectrical devices because of novel electrical and optical properties. For these device applications, it is necessary to prepare an epitaxial film of BIT.

In the past reports, the BIT films were prepared by physical vapor deposition (PVD) methods, i.e. rf sputtering [1, 2], ECR plasma sputtering [3] and pulse laser deposition [4]. In resent, we succeeded in preparing a BIT film which have a high quality of crystallinity and fully developed crystallographic orientation at low substrate temperatures by using an ECR plasma sputtering method [5]. However, it was difficult to control precisely the composition of film to obtain sufficient properties.

Chemical vapor deposition (CVD) methods were also applied to prepare the BIT film [6-10]. In general, the CVD methods are known to be superior to controlling of the film composition. However, the lowest deposition temperature to obtain the BIT film is around $580^{\circ} \mathrm{C}$ and the films prepared exhibit low crystallinity.

In order to prepare the BIT films with well-controlled composition and crystallinity at low temperatures, we have adopted a new method by the combination of ECR plasma sputtering and CVD (ECR plasma sputtering-CVD). In the present paper, we report a newly developed equip- 
ment, preparation conditions of the BIT film by this method and their crystallographic orientation and ferroelectric properties.

\section{EXPERIMENT}

Figure 1 shows the schematic diagram of the ECR plasma sputtering CVD apparatus used.

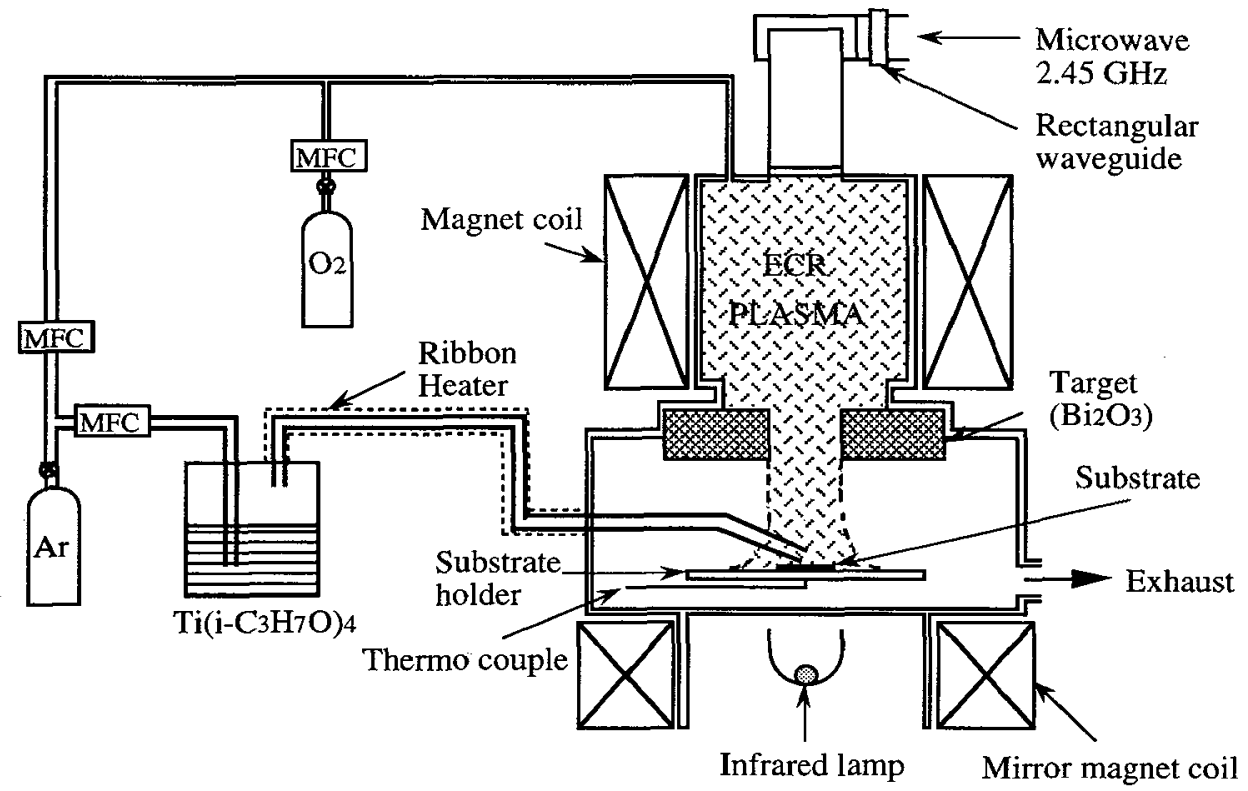

Figure 1: Schematic diagram of the ECR plasma Sputtering CVD apparatus.

Ti source was introduced from $\mathrm{Ti}\left(\mathrm{i}-\mathrm{C}_{3} \mathrm{H}_{7} \mathrm{O}\right)_{4}$ which was placed in a stainless steel bubbler heated in an oil bath. The Ti source was carried into a reactor by Ar gas.

The target of sputtering was a sintered $\mathrm{Bi}_{2} \mathrm{O}_{3}$ ceramic with a ring shape of $100 \mathrm{~mm}$ I.D., 110 $\mathrm{mm}$ O.D. and $50 \mathrm{~mm}$ height. The target was set at the plasma extraction port and RF power of 13.56 $\mathrm{MHz}$ was supplied to the target. A microwave $(2.45 \mathrm{GHz}, 500 \mathrm{~W})$ was introduced into the ion chamber through a rectangular wave guide. A magnetic field (875 Gauss) was applied to the ion chamber to satisfy the ECR condition. A mirror-type magnetic field (450 Gauss at the substrate stage) was applied in order to raise a plasma density, which results in an increase of the deposition rates of films.

The substrate used was a $\mathrm{MgO}(100)$ crystal $(10 \mathrm{~mm} \times 10 \mathrm{~mm} \times 1.0 \mathrm{~mm}$ ) courted with epitaxial $\mathrm{Pt}(100)$ which is necessary to measure ferroelectric properties. The substrate was heated up to $650^{\circ} \mathrm{C}$ using an infrared lamp. The substrate temperature was measured by a Pt-13\% PtRh thermocouple. The apparatus was evacuated at $5.0 \times 10^{-7}$ Torr by a turbo molecular pump and then $\operatorname{Ar} 10 \%-90 \% \mathrm{O}_{2}$ mixture gas $\left(30 \mathrm{~cm}^{3} / \mathrm{min}\right)$ was introduced into the chamber. The gas pressure during deposition was $1.1 \times 10^{-3}$ Torr and the deposition time was from 30 to 180 minutes. After deposition, the apparatus was cooled down to room temperature at the rate of about 100 ${ }^{\circ} \mathrm{C} / \mathrm{min}$. Deposition conditions are summarized in Table 1. 
Table 1: Deposition conditions of $\mathrm{Bi}_{4} \mathrm{Ti}_{3} \mathrm{O}_{12}$ film by ECR plasma Sputtering CVD method.

\begin{tabular}{|c|c|c|}
\hline $\begin{array}{l}\text { Substrate } \\
\text { Substrate temperature } \\
\text { Oxidation gas frow rate }\left(\mathrm{O}_{2}\right) \\
\text { Gas pressure } \\
\text { Deposition time } \\
\text { CVD }\end{array}$ & & $\begin{array}{l}: \text { Pt }(100) \text { on } \mathrm{Mg}(100) ; \mathrm{Pt}<100>/ / \mathrm{MgO}<100> \\
: 650^{\circ} \mathrm{C} \\
: 25 \mathrm{~cm}^{3} / \mathrm{min} \\
: 1.1 \times 10^{-3} \mathrm{Torr} \\
: 30-180 \mathrm{~min}\end{array}$ \\
\hline$\overline{\text { Source }}$ & & $: \mathrm{Ti}\left(\mathrm{i}-\mathrm{C}_{3} \mathrm{H}_{7} \mathrm{O}\right)_{4}$ \\
\hline Ti bubbler temperature & {$\left[\mathrm{T}_{\mathrm{Ti}}\right]$} & $=\quad 45-90^{\circ} \mathrm{C}$ \\
\hline Ribbon heater temperature & & $: 100^{\circ} \mathrm{C}$ \\
\hline $\begin{array}{l}\text { Carrier gas flow rate (Ar) } \\
\text { Bubbler pressure } \\
\text { Sputtering }\end{array}$ & {$\left[\mathrm{F}_{\mathrm{Ti}}\right]$} & $\begin{array}{l}: \quad 7-50 \mathrm{~cm}^{3} / \mathrm{min} \\
: 0.5 \mathrm{~atm}\end{array}$ \\
\hline Target & & $: \mathrm{Bi}_{2} \mathrm{O}_{3}$ \\
\hline Sputtering gas flow rate (Ar) & & $: 5 \mathrm{~cm}^{3} / \mathrm{min}$ \\
\hline ECR coil current & & $: \quad 21 \mathrm{~A}$ \\
\hline Mirror coil current & & $: \quad 12 \mathrm{~A}$ \\
\hline Microwave power & & : $500 \mathrm{~W}$ \\
\hline Target RF power & {$\left[P_{R F}\right]$} & $: 200-700 \mathrm{~W}$ \\
\hline Target-substrate distance & & : $160 \mathrm{~mm}$ \\
\hline
\end{tabular}

The composition of films was analyzed by an inductively coupled plasma emission spectrochemical apparatus (Shimadzu: P-5200) and a X-ray fluorescence apparatus (Rigaku: system3270). The thickness of films was measured by a thickness tester (Talystep). The structure of films was characterized by $\mathrm{X}$-ray diffraction analysis using $\mathrm{CuK} \alpha$ radiation (XRD: Rigaku RAD-C system). Preferred orientation and epitaxial relationship were evaluated by the rocking curve of BIT(008) peak and the pole figure, respectively. Ferroelectric hysteresis was measured at $50 \mathrm{~Hz}$ using a Sawer and Tower bridge circuit [11].

\section{RESULTS AND DISCUSSION}

Figure 2 shows the effect of Ti source temperature $\left(\mathrm{T}_{\mathrm{Ti}}\right)(\mathrm{a})$, deposition time $(\mathrm{b})$ and carrier gas flow rate $\left(\mathrm{F}_{\mathrm{Ti}}\right)(\mathrm{c})$ on the thickness of $\mathrm{TiO}_{2}$ films prepared by CVD process using the Ti source. The deposition rate of $\mathrm{TiO}_{2}$ films is increased with increasing $\mathrm{Ti}$ source temperature, deposition time and carrier gas flow rate. These results indicate that the amount of Ti deposition in the films can be controlled by $\mathrm{T}_{\mathrm{Ti}}$ and $\mathrm{F}_{\mathrm{Ti}}$ as well as by deposition time.

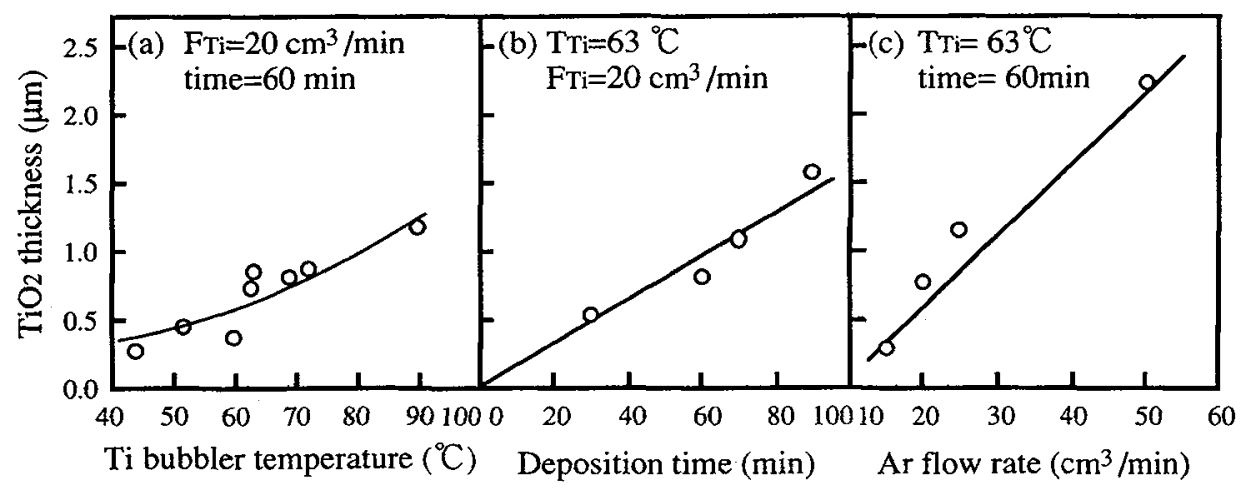

Figure 2: Thickness of $\mathrm{TiO}_{2}$ films versus (a) $\mathrm{Ti}$ bubbler temperature, (b) deposition time and (c) Ar flow rate. 


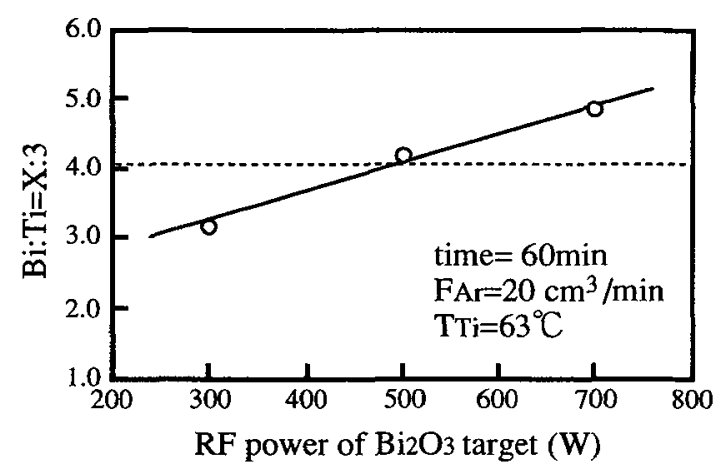

Figure 3: RF power dependence of the film composition.

Figure 3 shows the dependence of the RF power of $\mathrm{Bi}$ target $\left(\mathrm{P}_{\mathrm{RF}}\right)$ on the Bi:Ti ratio of film composition for $\mathrm{T}_{\mathrm{Ti}}=63{ }^{\circ} \mathrm{C}$, time $=60 \mathrm{~min}$ and $\mathrm{F}_{\mathrm{Ti}}=20 \mathrm{~cm}^{3} / \mathrm{min}$. The Bi content of films is increased linearly with the target $R F$ power. This means that the Bi:Ti ratio can be controlled by $\mathbf{P}_{\mathrm{RF}}$.

Figure 4 shows $\mathrm{X}$-ray diffraction patterns of the films having (a) an excess of Ti, (b) stoichiometric composition of $\mathrm{Ti}: \mathrm{Bi}$ and (c) an excess of $\mathrm{Bi}$ compared with the BIT phase. The BIT phase is observed in these films. But the film with an excess of Ti contains $\mathrm{Bi}_{2} \mathrm{Ti}_{2} \mathrm{O}_{7}$ phase as seen in Fig. 4 (a) and the film with an excess of $\mathrm{Bi}$ contains $\mathrm{Bi}_{12} \mathrm{TiO}_{20}$ as seen in Fig. 4 (c) as

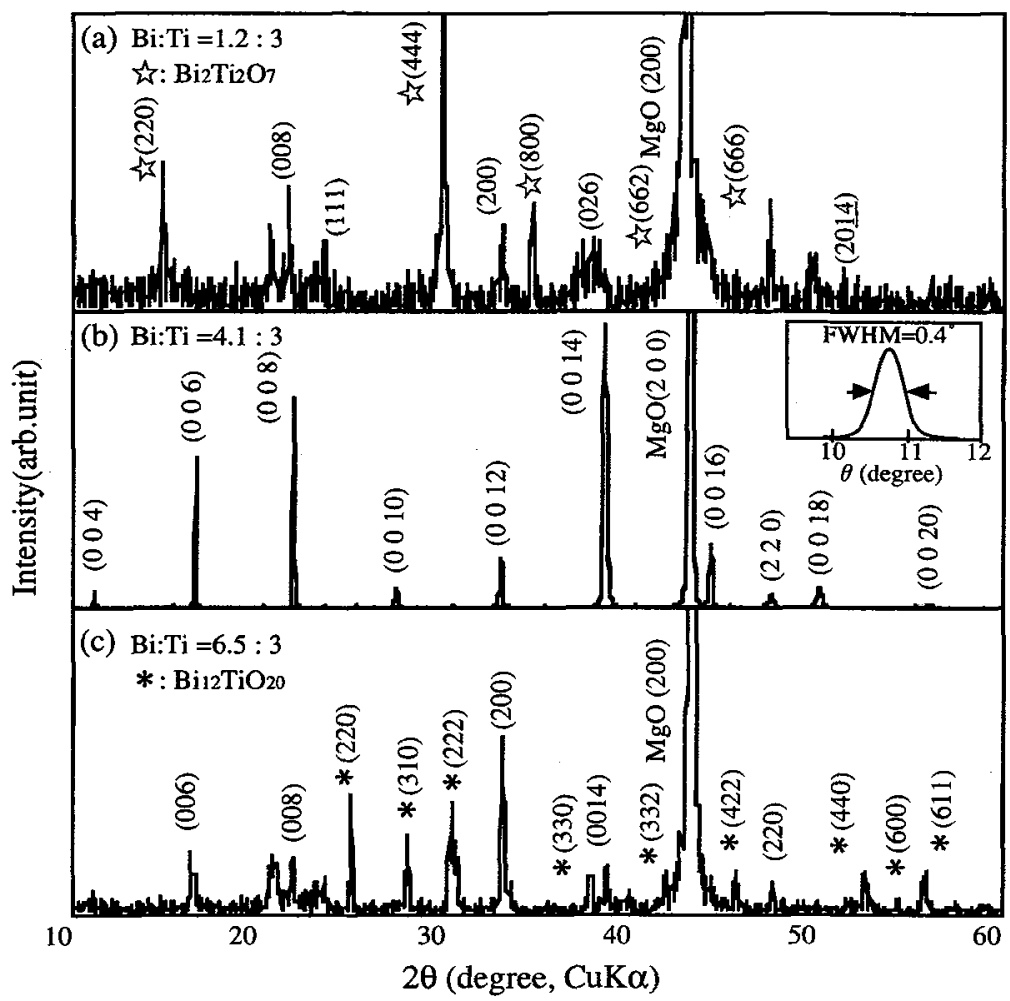

Figure 4: $X$-ray diffraction patterns of BIT films deposited at (a) $P_{R F}=700 \mathrm{~W}, T_{T i}=63^{\circ} \mathrm{C}$, (b) $P_{R F}=500 \mathrm{~W}, T_{T i}=63{ }^{\circ} \mathrm{C}$ and (c) $P_{\mathrm{RF}}=500 \mathrm{~W}, \mathrm{~T}_{\mathrm{Ti}}=90^{\circ} \mathrm{C}$. 
second phases. In Fig. 4 (b), it is seen that the film with the stoichiometric composition consists of a BIT single phase and the (001) plane of BIT is oriented parallel to the substrate surface. The full width at half maximum (FWHM) of BIT(008) rocking curve was estimated to be about $0.4^{\circ}$. This value indicates that the film obtained has excellent crystallinity in comparison with the CVD film (about $2.2^{\circ}$ ) prepared at $650^{\circ} \mathrm{C}$ [12]. The deposition rate was about $14 \mathrm{~nm} / \mathrm{min}$.

Figure 5(a) indicates the pole figure taken from (110) reflection of the BIT film. In the figure, four poles observed at $\alpha$ angle of $45^{\circ}$ and $\beta$ angles of every $90^{\circ}$ are a contour line indicating $50 \%$ of the maximum intensity. This means that epitaxial growth of the BIT film on $\mathrm{MgO}(100) / / \mathrm{Pt}(100)$ substrate takes place with a crystallographic relation as shown in fig. 5 (b)
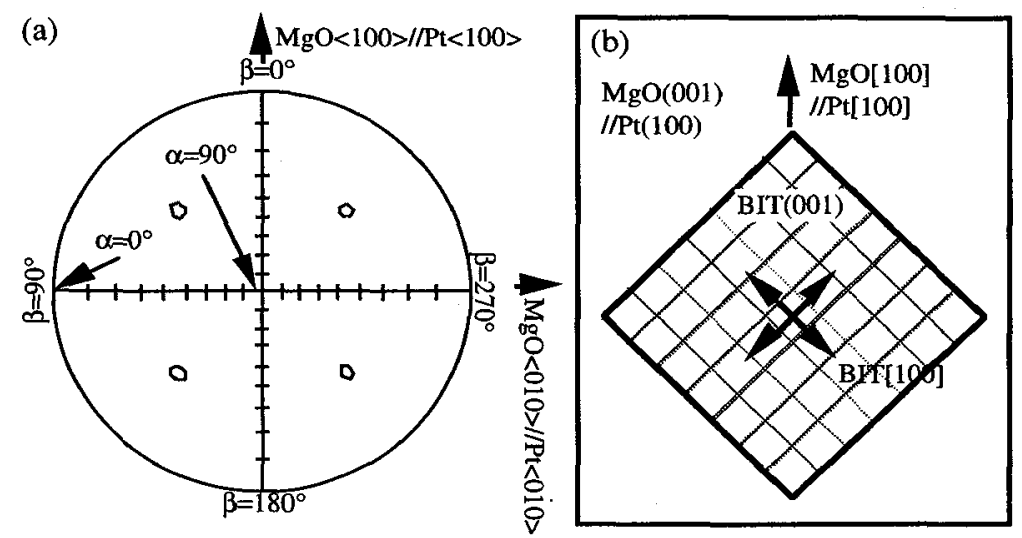

Figure 5: (a) X-ray pole figure of the BIT film deposited on the $\mathrm{MgO}(100) / / \mathrm{Pt}(100)$ substrate and (b) the direction relationship between the $\mathrm{MgO}(100) / / \mathrm{Pt}(100)$ substrate and (001) oriented BIT film.

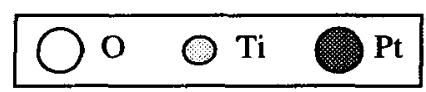

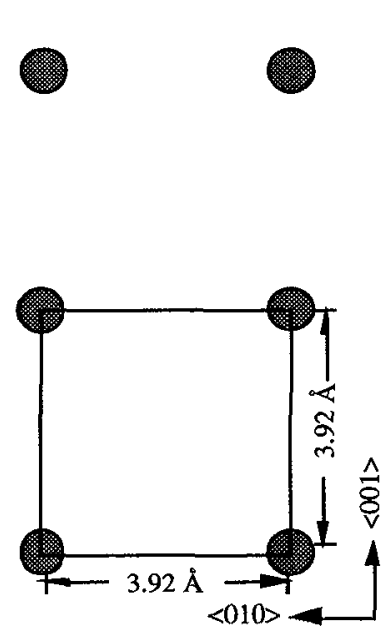

(a) Pt (100)

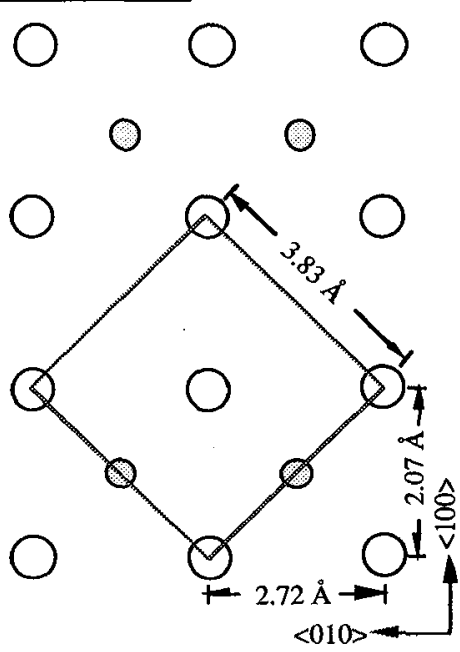

(b) BIT (001)

Figure 6: Atomic configuration on (a) Pt(100) and (b) BIT(001) planes. 
and the relationship is expressed as $\mathrm{MgO}(100) / / \mathrm{Pt}(100) / / \mathrm{BIT}(001)$ and $\mathrm{MgO}<100>/ / \mathrm{Pt}<100>/ /$ $\mathrm{BIT}<110>$.

In Fig. 6, the atomic arrangements of BIT(001) and $\mathrm{Pt}(100)$ plane are illustrated. The distance between the atoms in $<100>$ of Pt is $3.92 \AA$, which is close to the distances ( $3.83 \AA$ ) between the oxygen atoms in $\langle 110\rangle$ direction on BIT $(100)$. Such a small mismatch probably results in epitaxial growth of the BIT phase on the $\mathrm{Pt}(100)$ surface.

Figure 7 shows a ferroelectric hysteresis loop of the BIT film prepared at $\mathrm{T}_{\mathrm{Ti}}=63^{\circ} \mathrm{C}, \mathrm{F}_{\mathrm{Ti}}=20$ $\mathrm{cm}^{3} / \mathrm{min}, \mathrm{P}_{\mathrm{RF}}=500 \mathrm{~W}$ and time $=180 \mathrm{~min}$. The values of the residual polarization $(\mathrm{Pr})$ and the coercive field (Ec) estimated from the loop are $46 \mathrm{kV} / \mathrm{cm}$ and $1.12 \mu \mathrm{C} / \mathrm{cm}^{2}$, respectively These values are superior to those of the BIT film prepared by CVD at $580^{\circ} \mathrm{C}[7]$.

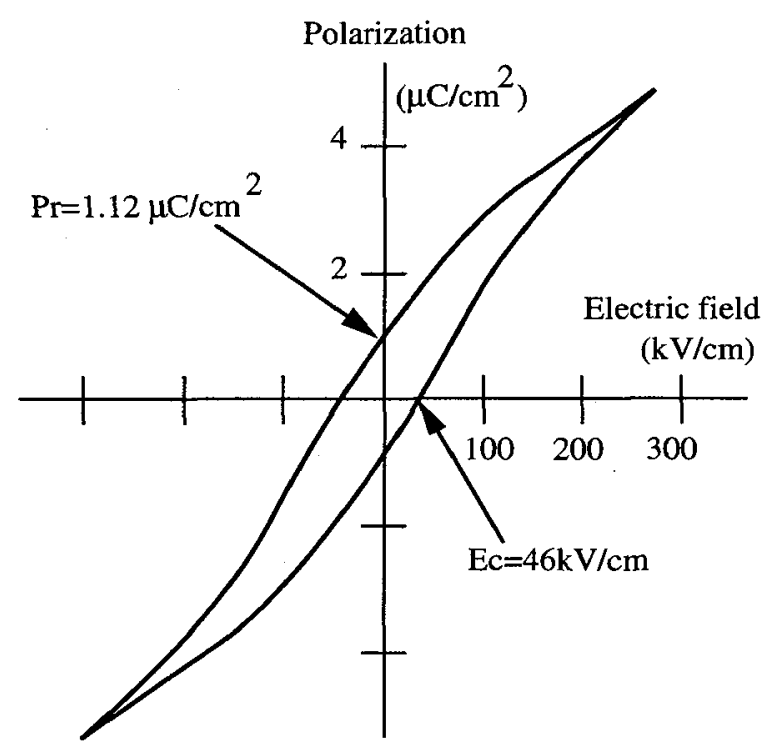

Figure 7: D-E hysteresis loop of the BIT film prepared by the ECR plasma sputtering CVD method.

\section{CONCLUSION}

Thin films of $\mathrm{Bi}_{4} \mathrm{Ti}_{3} \mathrm{O}_{12}$ were prepared by using an ECR plasma sputtering-CVD method, where $\mathrm{MgO}(100)$ courted by $\mathrm{Pt}(100)$ as substrate, $\mathrm{Bi}_{2} \mathrm{O}_{3}$ ceramic as sputtering target and tetraisopropoxy-titanium $\left[\mathrm{Ti}\left(\mathrm{i}-\mathrm{C}_{3} \mathrm{H}_{7} \mathrm{O}\right)_{4}\right]$ as CVD source were employed.

The composition ratio of $\mathrm{Bi}$ and $\mathrm{Ti}$ in films was controlled by $\mathrm{RF}$ power of $\mathrm{Bi}_{2} \mathrm{O}_{3}$ target and bubbling temperature of $\mathrm{Ti}$ source. The film having stoichiometric composition exhibited the single phase. The BIT crystal showed epitaxial relationships against the substrate surface $\mathrm{Pt}(100)$ as follows;

$\mathrm{MgO}(100) / / \mathrm{Pt}(100) / / \mathrm{BIT}(001)$ and $\mathrm{MgO}<100>/ / \mathrm{Pt}<100>/ / \mathrm{BIT}<110>$.

The values of residual polarization and coercive field estimated from a ferroelectric hysteresis loop were $46 \mathrm{kV} / \mathrm{cm}$ and from $1.12 \mu \mathrm{C} / \mathrm{cm}^{2}$, respectively. 


\section{Acknowledgments}

The BIT films were prepared at Laboratory for Developmental Research of Advanced Materials of the Institute for Materials Research, Tohoku University. This work was supported in part by a Grant-in-Aid for Encouragemental Scientific Research No. 05403017 and No. 06855075, a Grant-in-Aid for New Program under Contract No. 03NP0501 from the Ministry of Education, Science and Culture, Japan and the Murata Science Foundation.

\section{Reference}

[1] W. J. Takei, N. P. Formigoni and M. H. Francombe, Appl. Phys. Lett., 15 (1969) 256.

[2] Shu-Yau Wu: J. Appl. Phys., 50 (1979) 4314.

[3] H. Masumoto, T. Goto and T. Hirai, Appl. Phys. Lett., 55 (1989) 498.

[4] R. Ramesh, K. Luther, B. Wilkenes, D. L. Hart, E. Wang and J. M. Tarascon, Appl. Phys. Lett., 57 (1990) 1505.

[5] H. Masumoto, T. Goto, Y. Masuda, A. Baba and T. Hirai, J. Jpn. Soc. Powder and Powder Metall., 39(1991) 109.

[6] H. Masumoto, M. Namerikawa, H. Yamane and T. Hirai, J. Jpn. Soc. Powder and Powder Metall., 40(1993) 693.

[7] H. Masumoto, M. Namerikawa and T. Hirai, "Preparation of bismuth titanate films by chemical vapor deposition.", Proc. of 1st conf. on Processing materials for properties, Hawaii, November 7-10, 1993, H. Henein and T. Oki Eds., The Minerals, Metals and materials Society, pp. 1113.

[8] K. Yoshimura, S. Okamura and T. Tsukamoto, J. Ceram. Soc. Jpn., 105 (1994) 512.

[9] L. A. Wills and W. Wessels, Electrochem. Soc., 90-2 (1990) 781.

[10] M. Miyajima, R. Muhammet and M. Okada, Bull. Chem. Soc. Jpn., 10 (1991) 1373.

[11] C. B. Sawyer and C. H. Tower, Phys. Rev., 35 (1930) 269.

[12] H. Masumoto, Dr. thesis, Tohoku university (Engineering), Sendai, Japan (1994). 